\title{
A comparative study on the deterioration of oils by microwave and conventional heating
}

\author{
By Radwan S. Farag1, Fawzy M. Hewedi', Salah H. Abo-Raya ${ }^{2}$ and Gamal S. A. El-baroty ${ }^{1}$ \\ 1. Biochemistry Department, Faculty of Agriculture, Cairo University. \\ 2. Food Science and Technology Department, Faculty of Agriculture, Cairo University, Giza - Egipt.
}

\section{RESUMEN}

Estudio comparativo sobre la deterioración de aceites por calentamiento en microonda y convencional.

Se han calentado aceites de semilla de algodón y de palma hidrogenado mediante dos métodos: convencionalmente en cocina de gas y microonda. Se han determinado como métodos de garantía de calidad el índice de refracción, color, contenido en dienos, indice de acidez, índice de peróxido, índice de TBA, indice de iodo, contenido en ácidos grasos oxidados insolubles en éter de petróleo y grado de polimerización.

La exposición de las muestras de aceite a varios tiempos de calentamiento y potencia del horno microonda causó hidrólisis hacia ácidos grasos libres, aceleró la formación de hidroperóxidos y productos de oxidación secundarios. Los valores para cada test aumentaron con los ajustes de potencia del horno microonda y el tiempo de calentamiento. En general, el desarrollo de la rancidez para aceite de semilla de algodón refinado calentado por microonda fue 2 veces más rápido que el producido por calentamiento convencional.

También, los indices químicos para aceites de semilla de algodón refinado fueron mucho mayores que los de aceite de palma hidrogenado en todos los casos.

PALABRAS-CLAVE: Aceite de palma hidrogenado - Aceite de semilla de algodón - Alteración termooxidativa - Calentamiento convencional - Calentamiento en microonda - Estudio comparativo.

\section{SUMMARY}

A comparative study on the deterioration of oils by microwave and conventional heating.

Refined cottonseed oil and hydrogenated palm oil were heated by two methods, i.e., conventionally by gas-cooker and microwaves. Quality assurance methods such as refractive index, color, diene content, acid value, peroxide value, TBA value, iodine value, petroleum ether insoluble oxidized fatty acid content and degree of polymerization were determined. Exposing the oil samples to various heating times and microwave oven power caused some hydrolysis to free fatty acids, accelerated the formation of hydroperoxides and secondary oxidation products. The values from each test increased with both the power settings of microware oven and time of heating. In general, the development of rancidity for refined cottonseed oil heated by microwaves was twice faster than that produced by conventional heating. Also, the chemical values for refined cottonseed oil were much higher than that of hydrogenated palm oil in all cases.
KEY-WORDS: Comparative study - Conventional heating Cottonseed oil - Hydrogenated palm oil - Microwave heating Thermooxidative alteration.

\section{INTRODUCTION}

Deep-fat frying process is one of the most commonly used procedures for the preparation and production of foods throughout the world. During the deep-fat frying process, the oil is continuously heated at high temperatures in the presence of moisture and atmospheric oxygen. Under these conditions, oxidation, polymerization and degradation occur (1). These reactions lead to the changes in functional, sensory and nutritional quality of fried foods which may result in adverse effects on consumer health (2).

Microwave heating has been applied extensively to the processing of food products during the last decade. It is more energy efficient and reduces the cooking time as compared to conventional heating (3). Speed and time saved are usually the most attractive feature of microwave heating. Consequently, microwaves are used in the food industry not only for thawing, drying and baking (4) but for other applications such as pasteurization and sterilization of many types of foods (5), (6), (7), (8), (9). Short time microwave heating of peanuts yielded a $95 \%$ reduction of the aflatoxin content without measurable changes in the protein and lipid concentrations (10).

It seems that there is little information concerning the effect of microwave heating on the chemical composition and nutritional quality of the cooked foods. In addition, recently some questions about the safety of microwave ovens for food cooking has been raised. Consequently, the main objective of the present work was to study the effect of microwave heating on the physical and chemical characteristics and keeping quality of refined cottonseed oil and hydrogenated palm oil. Conventional heating was conducted simultaneously 
with the microwave heating in order to envisage the differences between the two heating methods on the aforementioned oil samples.

\section{MATERIALS AND METHODS}

\section{Cottonseed oil and hydrogenated palm oil}

Refined cottonseed oil was obtained from the Cairo Company for oil and Soap. Its peroxide and acid values were 5.2 and 0.2 , respectively. Hydrogenated palm oil was obtained from Misr Gulf Company for Oil Industrialization and its peroxide and acid values were 1.0 and 0.11 , respectively. Both oil samples were free from synthetic antioxidants.

\section{Thermal heating}

Microwave oven used for oil heating was Moulinex electronic type 823 (France). The frequency of the radiation emitted in this oven was ca $60 \mathrm{~Hz}$. There were three levels or settings of heating corresponding to low, moderate and full power and when operated at full power it provides ca $1300 \mathrm{~W}$. The hydrogenated palm oil and refined cottonseed oil $(200 \mathrm{~g}$ oil in 500 $\mathrm{ml}$ glass beaker) were placed on a turn table and drive which slowly rotated the oil samples to obtain uniform heating. The samples were heated by microwaves for various periods $(2,4,6$ and $8 \mathrm{~min})$, at each power settings. Comparative experiments using gas cooker (conventional heating) were conducted for 4,8 and 16 min. The microwave oven temperatures at various heating times and power settings were determined by inserting a caliberated glass thermometer into the oil samples. Table I shows the internal temperatures of oil samples heated conventionally and by microwaves. Samples from the oil samples under study were physically and chemically analyzed at each heating time and power setting.

Table 1

Internal temperatures of lipids heated conventionally and by microwaves.

\begin{tabular}{|c|c|c|c|c|c|c|c|}
\hline \multirow{2}{*}{ Power setting } & \multicolumn{4}{|c|}{ Heating time (min) } & \multicolumn{3}{|l|}{$\cdot$} \\
\hline & 2 & 4 & 6 & 8 & 4 & 8 & 16 \\
\hline & \multicolumn{4}{|c|}{ Microwave heating $\left({ }^{\circ} \mathrm{C}\right)$} & \multicolumn{3}{|c|}{ Conventional heating $\left({ }^{\circ} \mathrm{C}\right)$} \\
\hline & \multicolumn{7}{|c|}{ Refined cottoseed o1l } \\
\hline Low power (I) & $87 \pm 2$ & $117 \pm 2$ & $142 \pm 2$ & $156 \pm 2$ & $145 \pm 2$ & $248 \pm 2$ & $>250$ \\
\hline Moderate power (II) & $100 \pm 2$ & $148 \pm 2$ & $152 \pm 2$ & $172 \pm 2$ & & & \\
\hline \multirow[t]{2}{*}{ Full power (III) } & $110 \pm 2$ & $170 \pm 2$ & $182 \pm 2$ & $230 \pm 2$ & & & \\
\hline & \multicolumn{7}{|c|}{ Hydrogenated palm oil } \\
\hline Low power (I). & $65 \pm 2$ & $106 \pm 2$ & $155 \pm 2$ & $166 \pm 2$ & $138 \pm 2$ & $238 \pm 2$ & $>250$ \\
\hline Moderate power (II) & $78 \pm 2$ & $140 \pm 2$ & $168 \pm 2$ & $184 \pm 2$ & & & \\
\hline Full power (III) & $96 \pm 2$ & $182 \pm 2$ & $208 \pm 2$ & $222 \pm 2$ & & & \\
\hline
\end{tabular}

\section{Quality assurance methods}

Physical and chemical determinations included refractive index, spectrophotometric determinations of color and diene content, acid value, peroxide value, iodine value and TBA value for the lipids under study were determined (11) (12). The degree of polymerization (13) and petroleum ether insoluble oxidized fatty acids (14) were determined under both heating methods for hydrogenated palm oil and refined cottonseed oil. All samples were analysed in triplicate immediately after heating and cooling to room temperature and the mean values were presented in the text.

\section{Statistical analysis}

The data for physical and chemical tests for measuring the heated oil stability were statistically analysed (F-test) using the microcomputer statistical package "Statgraphics" Statistical system by Statistical Graphics Corporation.

\section{RESULTS AND DISCUSSION}

The changes in the acid value of refined cottonseed oil heated by microwaves for $8 \mathrm{~min}$ is shown in Fig 1. The low power microwave treatment did not 
significantly alter the acid value of refined cottonseed oil. Moderate and full power microwave treatment induced a linear increase in the hydrolysis of cottonseed oil measured by acid value. The extent of cottonseed oil hydrolysis was dependent upon the microwave oven power settings and the increase of the acid value was in the order: low power > moderate power > full power. The acid value of hydrogenated palm oil treated with microwave showed a slight, linear increase up to $8 \mathrm{~min}$. In general, the acid value for refined cottonseed oil at any level and heating period was much higher than that of hydrogenated palm oil. The liberation of small amounts of fatty acids from their triglycerides might be due to the influence of heat and moisture in the lipid materials and surrounding atmosphere.

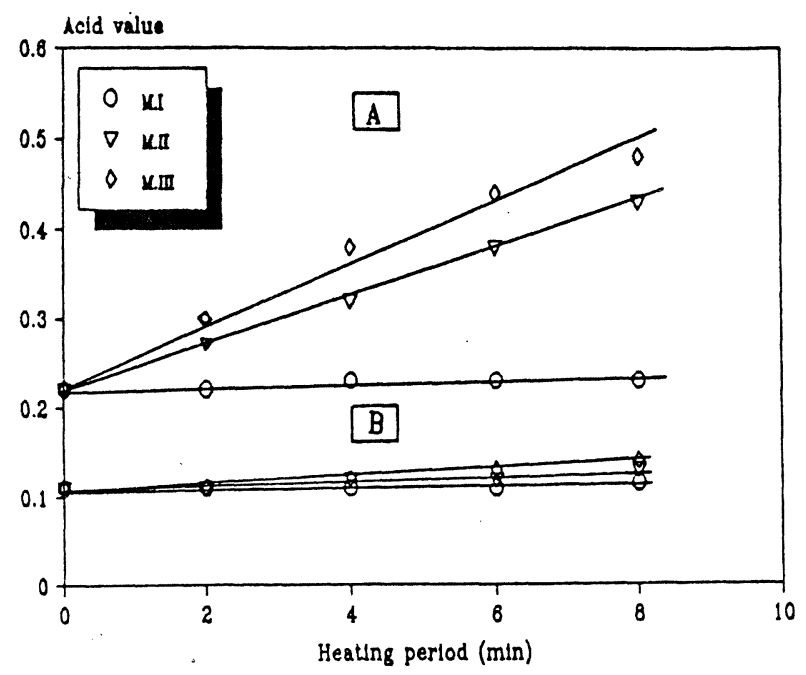

Fig. 1

Changes in Acid values during microwave heating of refined cottonseed oil (A) and hydrogenated palm oil (B) at different heating levels.

M.I, M.II and M.III refer to microwave heating at low, moderate and full power, respectively.

Peroxide values for microwave heated refined cottonseed oil increased at various oven power settings (Fig. 2). Heating refined cottonseed oil using microwave oven at low power caused a remarkable increase in the peroxide value after only $2 \mathrm{~min}$ of treatment and then increased linearly thereafter up to $8 \mathrm{~min}$. Surprisingly, the rate of hydroperoxide formation for cottonseed oil was the same at low, moderate and full power settings. The acceleration of cottonseed oil oxidation due to exposure to microwaves can be interpreted as follows. It is well known that microwaves cause high vibration to the molecules and in particular for the labile hydrogen atoms of the active methylene group adjacent to unsaturated centres. These atoms become too excited and the friction occurring causes a considerable and rapid build-up of heat which facilitates the abstraction of the hydrogen atom. The overall result is the production of free radicals which in turn rapidly react with the atmospheric oxygen and produce hydroperoxides.

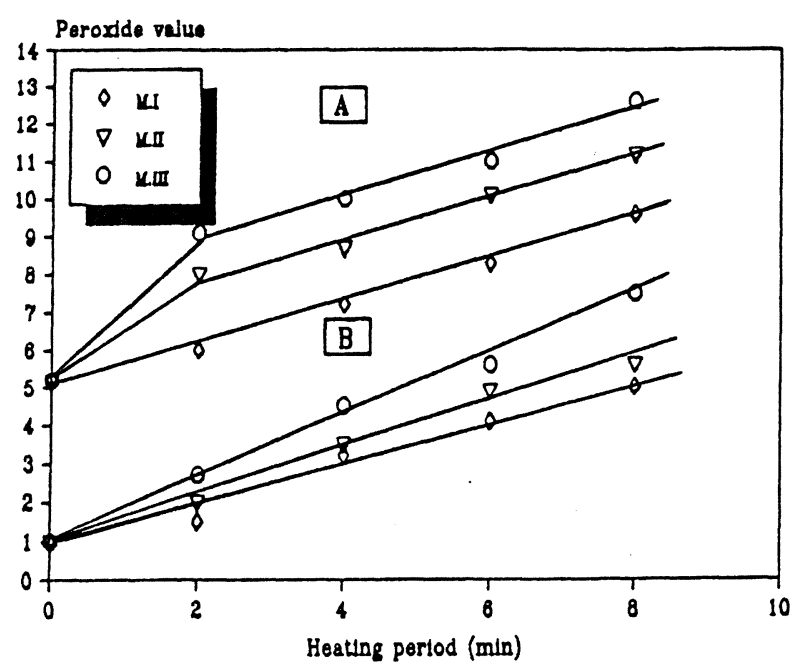

Fig. 2

Changes in Peroxide values during microwave heating of refined cottonseed oil (A) and hydrogenated palm oil (B) at different heating levels.

M.I, M.II and M.III refer to microwave heating at low, moderate and full power, respectively.

The peroxide value of hydrogenated palm oil increased linearly with both heating period and oven power. Hereagain, the effectiveness of microwave oven heating on the peroxide values for both refined cottonseed oil and hydrogenated palm oil was entirely dependent upon the oven power level, the full power of microwave oven produced the higher hydroperoxide content and vice versa with the low power. The peroxide value of the hydrogenated palm oil was always lower than that of refined cottonseed oil in all cases. These results may be expected since the oxidation and consequently hydroperoxide formation of lipids is due mainly to their content of unsaturated fatty acids.

Fig. 3 presents the influence of microwave heating at various power levels on the TBA values for refined cottonseed oil and hydrogenated palm oil. $A$ linear relationship exists between the formation of secondary oxidation products and both the time that refined cottonseed oil is heated and microwave oven power settings. Generally speaking, the same findings for refined cottonseed oil were noticed with hydrogenated palm oil. However, the mechanism for the production of secondary oxidation materials was dependent upon the nature of lipid substances, a chain reaction mechanism may be operative with hydrogenated palm oil while a linear increase of the production of secondary oxidation substance took place with refined cottonseed oil. Refined cottonseed oil produ- 
ced higher levels of the secondary oxidation materials than hydrogenated palm oil. This findings was in parallel with the data of peroxide and acid values.

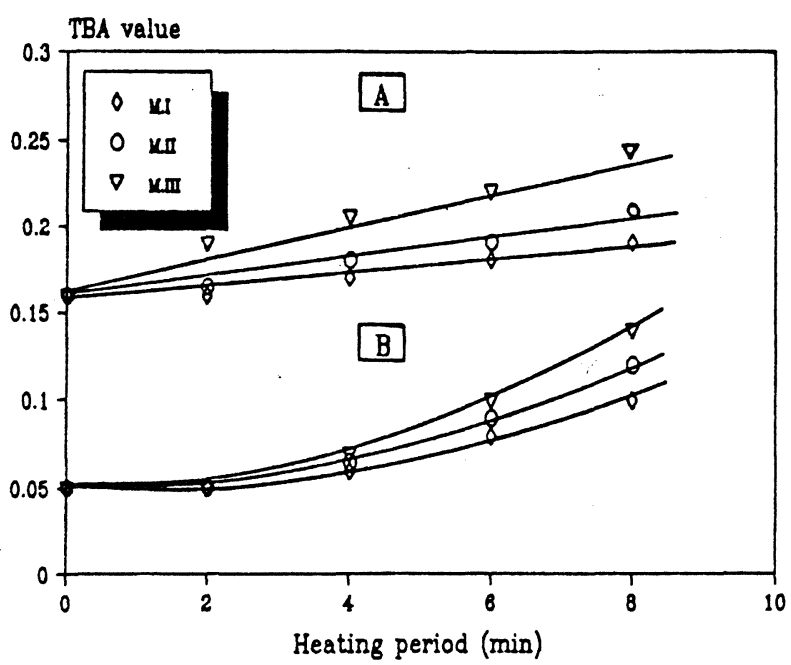

Fig. 3

Changes in TBA values during microwave heating of refined cottonseed oil (A) and hydrogenated palm oil (B) at different heating levels.

M.I, M.II and M.III refer to microwave heating at low, moderate and full power, respectively.

The slopes for peroxide and TBA values curves obtained from microwave heating at full power and conventional heating for refined cottonseed oil were the same (Figs. 2, 4, 5, 6). The peroxide and TBA values for refined cottonseed oil heated by microwave oven at full power for 8 min were similar to that obtained by conventional heating after $16 \mathrm{~min}$. This means that

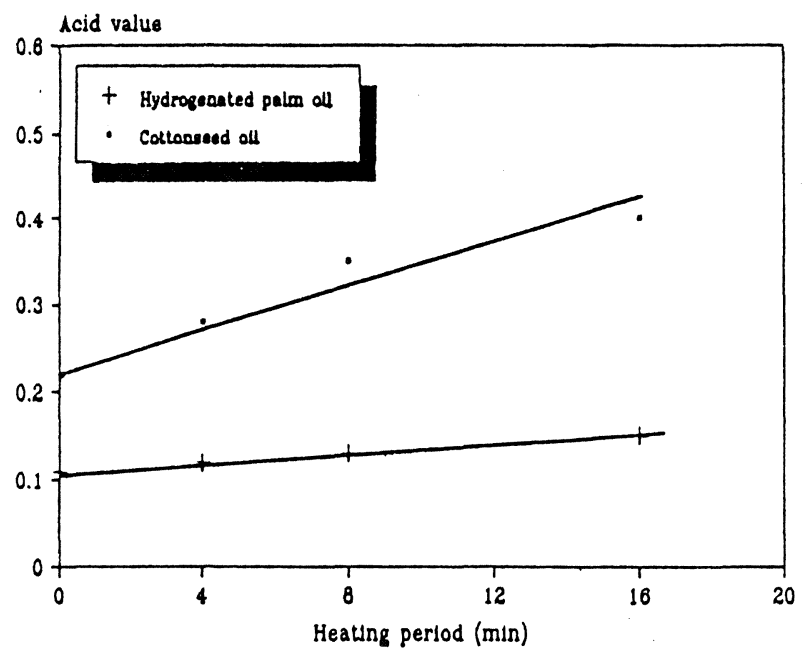

Fig. 4

Changes in Acid value during conventional heating of hydrogenated palm oil and refined cottonseed oil at different heating periods.

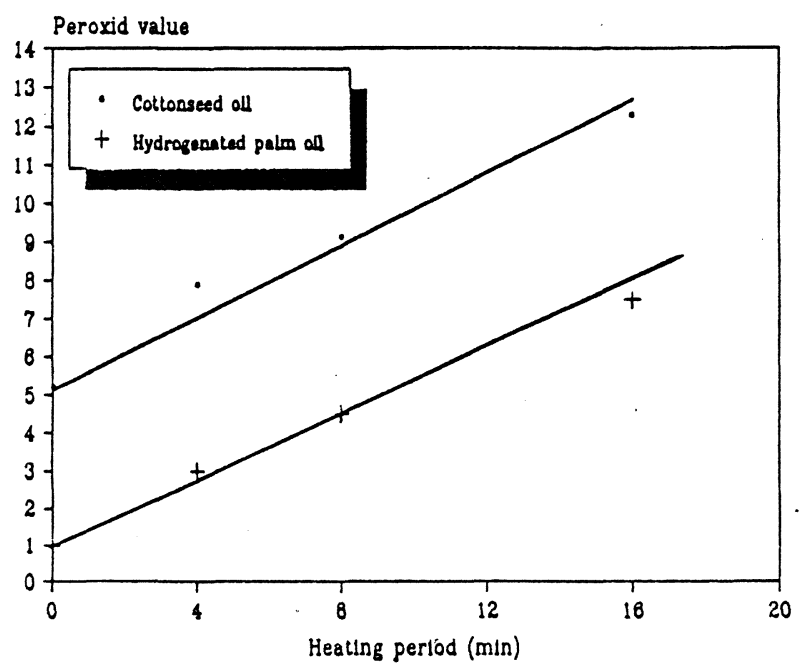

Fig. 5

Changes in Peroxide value during conventional heating of hydrogenated palm oil and refined cottonseed oil at different heating periods.

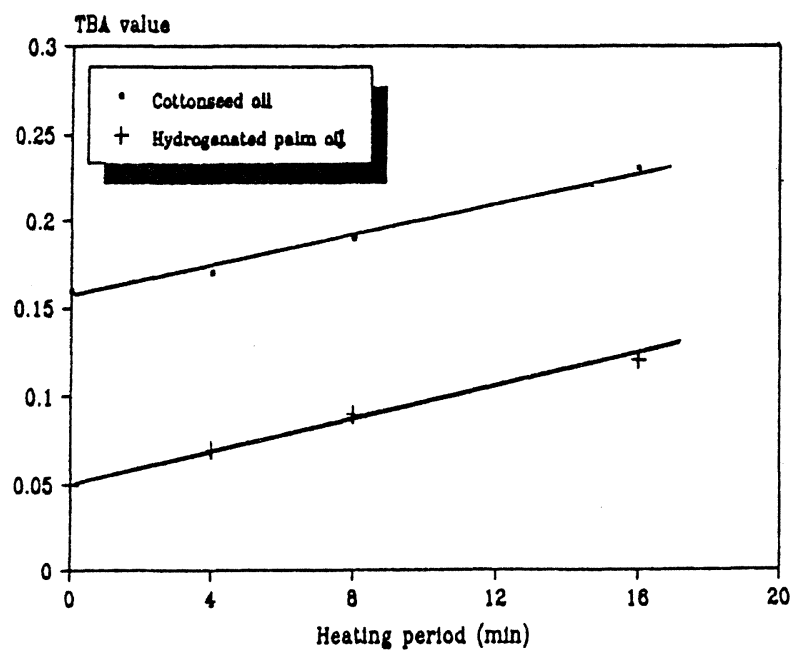

Fig. 6

Changes in TBA value during conventional heating of hydrogenated palm oil and refined cottonseed oil at different heating periods.

any peroxide value or TBA value for refined cottonseed oil was reached by microwave heating in about one-half the time that conventional heating requires. Generally speaking, the development of rancidity as measured by peroxide and TBA values for refined cottonseed oil heated by microwave oven was two times faster than that obtained by conventional heating.

The acid value curves (Figs. 1,4) indicate that the hydrolysis rate of hydrogenated palm oil heated by microwave oven at full power for $8 \mathrm{~min}$ was the same when heated by conventional method for $16 \mathrm{~min}$. Also, the rate of hydrolysis for refined cottonseed oil heated by microwave oven at moderate power was identical 
Table II

Effect of heat treatments on some physical and chemical properties of refined cottonseed oil.

\begin{tabular}{|c|c|c|c|c|c|c|}
\hline $\begin{array}{l}\text { Heating } \\
\text { time(min.) }\end{array}$ & Colour & $\begin{array}{l}\text { Refractive } \\
\text { Index }\end{array}$ & $\begin{array}{l}\text { Diene } \\
\text { content }\end{array}$ & $\begin{array}{l}\text { Iodine } \\
\text { Value }\end{array}$ & $\begin{array}{c}\text { Oxidized } \\
\text { Fatty Acids } \\
\%\end{array}$ & Polymers \\
\hline \multirow[t]{2}{*}{ Zero } & 0.89 & 1.4730 & 1.83 & 106.4 & 0.00 & 0.00 \\
\hline & \multicolumn{5}{|c|}{ Microwave Heatins (low nower) } & \\
\hline 2 & 0.91 & 1.4730 & 1.83 & - & - & - \\
\hline 4 & 0.90 & 1.4730 & 1.83 & - & - & - \\
\hline 6 & 0.90 & 1.4730 & 1.83 & - & - & - \\
\hline \multirow[t]{2}{*}{8} & 0.89 & 1.4730 & 1.83 & 106.3 & 0.00 & 0.00 \\
\hline & \multicolumn{6}{|c|}{ Microwave Heating (noderate nower) } \\
\hline 2 & 0.92 & 1.4730 & 1.83 & - & - & - \\
\hline 4 & 0.92 & 1.4730 & 1.83 & - & - & - \\
\hline 6 & 0.92 & 1.4730 & 1.83 & - & - & - \\
\hline \multirow[t]{2}{*}{8} & 0.91 & 1.4730 & 1.83 & 106.3 & 0.00 & 0.00 \\
\hline & \multicolumn{5}{|c|}{ Microwave Heatins (full nower) } & \\
\hline 2 & 0.90 & 1.4733 & 1.83 & - & - & - \\
\hline 4 & 0.90 & 1.4733 & 1.83 & - & - & - \\
\hline 6 & 0.89 & 1.4733 & 1.83 & - & - & - \\
\hline \multirow[t]{2}{*}{8} & 0.91 & 1.4734 & 1.83 & 106.2 & 0.00 & 0.00 \\
\hline & \multicolumn{5}{|c|}{ Conventional Heating } & \\
\hline 4 & 0.89 & 1.4730 & 1.83 & - & - & - \\
\hline 8 & 0.90 & 1.4730 & 1.83 & - & - & - \\
\hline 6 & 0.91 & $1.4732^{\circ}$ & 1.83 & 106.0 & 0.00 & 0.00 \\
\hline
\end{tabular}

to that obtained by conventional heating. Hereagain, the time required to obtain a particular acid value by conventional heating was nearly one-half that in microwave heating for both refined cottonseed oil and hydrogenated palm oil. In this respect, Yoshida et al. (15) determined peroxide, thiobarbituric acid, carbonyl and anisidine values of linseed, soybean, corn, olive and palm oils after microwave heating. The results indicated a general trend in which linseed oil was oxidized more rapidly than the other oils during the heat treatment and the rate of fatty acid breakdown is related to the number of double bonds in the carbon chain of the molecule.
Other parameters such as color, refractive index, diene content, iodine value, petroleum ether insoluble oxidized fatty acids and degree of polymerization for refined cottonseed oil and hydrogenated palm oil heated by microwaves and gas cooker were determined (Tables I, II). Microwave or conventional heating had no significant effect on these tests for refined cottonseed oil with heating period. The same results were found for hydrogenated palm oil (Table III) except for microwave heating at full power where highly significant increases for color, refractive index and diene content were noticed. It is worth mentioning that the heat treatments under experimental conditions did not 
Table III

Effect of heat treatments on some physical and chemical properties of hydrogenated palm oil.

\begin{tabular}{lllllll}
\hline $\begin{array}{l}\text { Heating } \\
\text { time(min.) }\end{array}$ & Colour & $\begin{array}{l}\text { Refractive } \\
\text { Index }\end{array}$ & $\begin{array}{l}\text { Diene } \\
\text { content }\end{array}$ & $\begin{array}{l}\text { Iodine } \\
\text { Value }\end{array}$ & $\begin{array}{l}\text { Oxidized } \\
\text { Fatty Acids } \\
\%\end{array}$ & $\%$ \\
\hline Zero & 0.88 & 1.4650 & 1.14 & 42.2 & 0.00 & 0.00
\end{tabular}

Mlcrowave Heating ( low power)

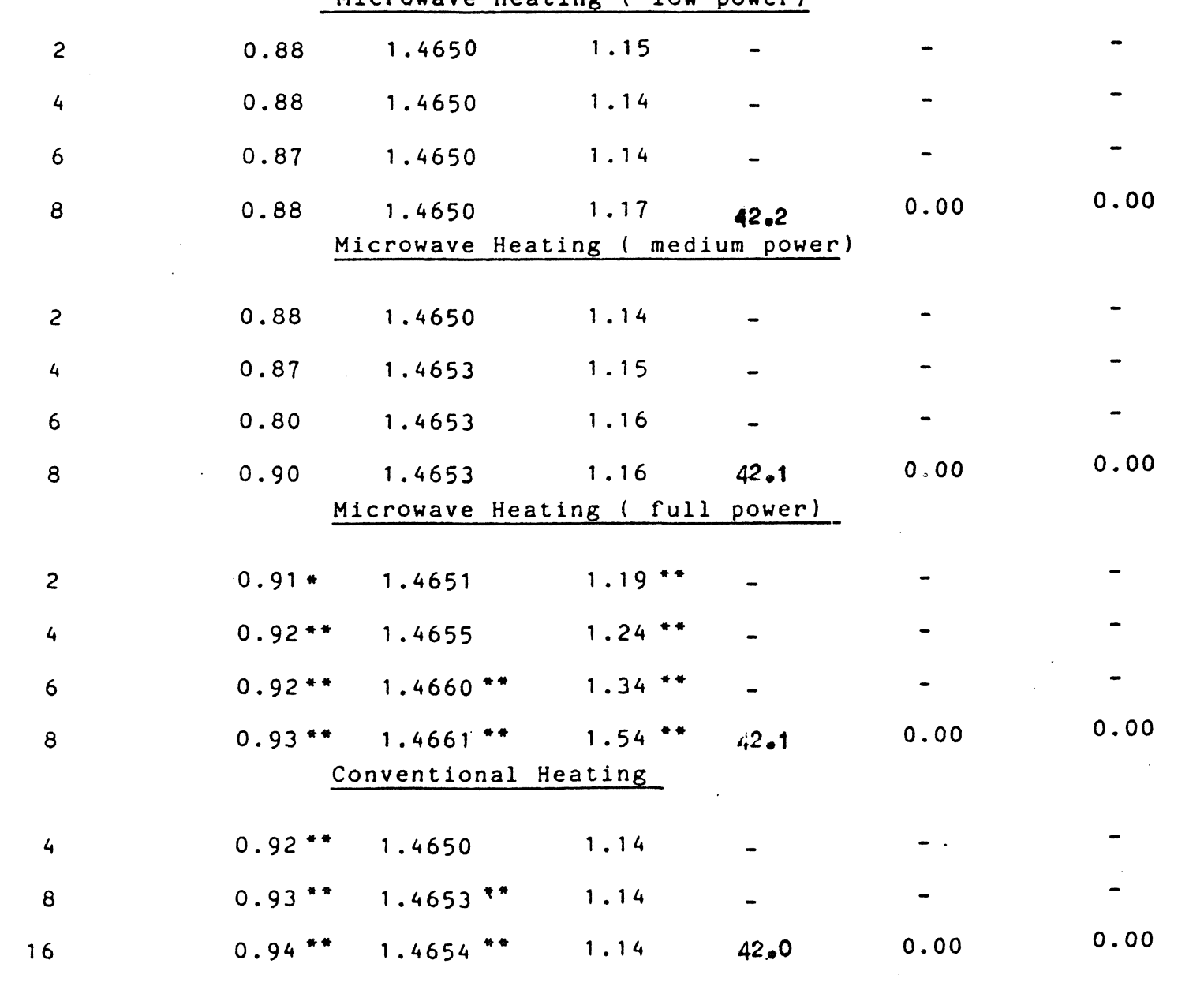

* and * refer to significant chantes at $p=0.05$ and $p=0.02$ levels, resuectivelj.

form both petroleum ether insoluble oxidized fatty acids and polymers. It is well established that polymerization takes place when an oil is heated above $300^{\circ} \mathrm{C}$ and the reaction during this process occur with linoleic-rich oils much slower than linolenic-rich oils and conjugated unsaturated acids polymerize extensively in a few min. (16). This statement lends weight to our findings.

With the increasing role of processed foods in our diets, some anxiety has been expressed to the way which the processed foods are cooked. It has been reported that vitamins adversely affected by novel processes such as extrusion and microwave cooking, cook-chill procedures and irradiation (17). In addition, the results of the present work demonstrated that exposing refined cottonseed oil to microwaves for 8 min significantly accelerated the formation of hydroperoxides. Hence, the fried foods absorb part of the hydroperoxides and these carcinogenic materials will be part of our diet and cause deleterious effect on our health. Consequently, one has to be very carefull in using microwave ovens for food cooking. 


\section{ACKNOWLEDGEMENT}

The authors would to acknowledge the interest, helpful suggestions and revising the manuscript offered by Prof. Dr. N. D. Camper, College of Agricultural Sciences, Department of Plant Pathology and Physiology, Clemson, South Carolina, USA.

\section{REFERENCES}

1. Perkins, E.G.-"Formation of Non-Volatile Decomposition Products in Heated Fats and Oils".-Food Technol. 21 (1967) 125-130.

2. Wu, P. and Nawar, W.W.-“A Technique for Monitoring the Quality of Used Frying Oils".-J.Am. Oil Chemists'Soc. 63 (1986) 13631367.

3. Merin, U. and Rosenthal, I.-Milschwissenschaft 39 (1984) 643.

4. Rosenberg, U. and Bögl, W.-"Microwave Thawing, Drying, and Baking in the Food Industry".-Food Technol. 41 (1987) 85-91.

5. Dunojski, E. and Stecki, W.-Przemyal Spozywizy 25 (1971) 80.

6. Ayoud, J.A., Berkowitz, D., Kenyon, E.M. and Wadsworth, C.K.-"Continuous microwave sterilization of meat in flexible Pouches".-J. Food Sci. 39 (1974) 309-313.

7. Foley, J. and Buckley, J.-Food and Nutrition. European Coorporation in Scientific and technical Research (Thermal Processiong Symp). (1978).

8. Bogucki, J.-Brzeglad Zbozowo-Mlynarski 25 (1981) 22.

9. Enani, Y. and Ikeda, T.-UK patent applic GB 2,098, 040 A. (1982).
10. Luter, L., Wyslouzil, W. and Kashyaps, S.C.-Can. Inst. Food Sci. Technol. J. 15 (1982) 236.

11. A.O.A.C.-"Official Methods of Analysis of the Association of Official Analytical Chemists".-Edited by Horwitz W.-15 th Ed.-Washington, D.C., 1975.

12. Ottolenghi, A.-Arch. Biochem. Biophys. 79 (1959) 355.

13. Peled, M., Gutfinger, T. and Letan, A.-"Effect of Water and BHT on Stability of Cottonseed Oil During Frying".-J. Sci. Food Agric. 26 (1975) 1655-1666.

14. Arens, M.M., Guhr, G., Waibel, J. and Kroll, S.-"Bestimmung des Gehaltes an petrolätherunlöslichen oxidierten Fettsäuren zur Beurteilung von Brat-und Siedefetten".-Fette Seifen Anstrichmitte 79 (1977) 310-314.

15. Yoshida, H., Hirooka, N. and Kajimoto, G.J.-Food Sci. 55 (1990) 1412.

16. Gunston, D.-"An introduction to the chemistry and biochemistry of fatty acids and their triglycerides".-Chapman and Hall Ltd.-11 New Fetter Lane London ECU, p 120. (1967).

17. Mills, E.N.C. and Morgan, M.R.A.-Food Technology International Europ.-Ed. Turner, A., Sterling Publications International Ltd. (1990) 227. 